\title{
A review of evolution of oviposition guilds in the Bruchidae (Coleoptera)
}

\author{
Clarence Dan Johnson ${ }^{1} \&$ Jesús Romero ${ }^{2}$
}

${ }^{1}$ Department of Biological Sciences, Northern Arizona University, Flagstaff, AZ, USA 86011-5640.

${ }^{2}$ Programa de Entomología y Acarología, CEIFIT, Colegio de Postgraduados, Montecillo, Estado de Mexico, Mexico.

\begin{abstract}
Resumo. Uma revisão das guildas de oviposição em Bruchidae (Coleoptera). Os bruquídeos apresentam três guildas de oviposição caracterizadas por períodos e maneiras diferentes de postura. Algumas espécies somente ovipositam nos frutos enquanto presos à planta (Guilda $\mathrm{A}$ ), outras somente em sementes expostas de frutos enquanto ainda estão na planta (Guilda B) e algumas apenas em sementes livres no substrato (Guilda C). Uma espécie de planta pode ser infestada nas três condições, outras somente por duas e outras por apenas uma condição. Muitos artigos científicos têm sido publicados antes e após o conceito das guildas e, ao que parece, o comportamento primitivo dos bruquídeos provavelmente foi o de ovipositar sobre os frutos, com as larvas penetrando através de sua parede para se alimentarem das sementes (Guilda A). Como a evolução dos frutos foi direcionada para a dispersão das sementes e, possivelmente, fuga da predação por bruquídeos, estes desenvolveram outras maneiras para se alimentar de sementes (Guilda B e C). Os dados indicam que cerca de $78 \%$ dos bruquídeos ovipositam em frutos e $22 \%$ se incluem nas Guildas B e C. Nesse trabalho são revistos e discutidos os artigos científicos sobre guildas de oviposição e a evolução de bruquídeos, bem como acrescentados novos dados.
\end{abstract}

Palavras-Chave. Fabaceae; guilda de oviposição; sementes; Stator.

\begin{abstract}
Three guilds of bruchid beetles oviposit on seeds at different times and in different ways, i. e., in these guilds some species only oviposit on fruits while on the plant (Guild A), other species only oviposit on seeds exposed in fruits while still on the plant (Guild B) and some only oviposit on seeds once they are exposed on the substrate (Guild C). It has been established that one plant species may be oviposited upon by all three guilds, some only by two guilds and some by only one guild. Before and after the inception of this concept many papers have been published that seem to establish that early oviposition behavior of bruchids was probably onto fruits where they burrowed through the fruit wall and fed on seeds (Guild A). Then, as evolution of the fruits developed for dispersal of seeds and possible escape from bruchid predation, bruchids developed to feed in seeds in various other ways (Guilds B and C). Our data show that about $78 \%$ of extant bruchids oviposit on fruits, and the other $22 \%$ with behavior of Guilds B and C. A review of these papers and new data on oviposition guilds and bruchid evolution are presented and discussed here.
\end{abstract}

Keywords. Fabaceae; oviposition guilds; seeds; Stator.

In 1959, Johnson first noticed different oviposition behavior in bruchids on fruits of Cercidium floridum Bentham ex A. Gray, 1852 that commonly had eggs glued to the outside of the fruits and to the seeds when the fruits were partially dehisced in the field. He then learned that the eggs glued to the fruits were those of Mimosestes amicus (Horn, 1873) and the eggs glued to the seeds were those of Stator limbatus (Horn, 1873). After many years of collecting fruits with seeds and bruchids in them, many with the behavior above, the final impetus for Johnson's research on oviposition guilds of bruchids was when he observed that the bruchid Stator pygidialis (Schaeffer, 1907) oviposits on seeds of Calliandra humilis Bentham, 1846 only after they have fallen from the fruit and by the report of BOTTIMER (1973) of similar behavior for the three rare species Stator mexicanus Bottimer, 1973, S. subaeneus (Schaeffer, 1907) and S. vachelliae Bottimer, 1973. What was most interesting about these discoveries was that in contrast to C. humilis, some plant seeds are fed upon by bruchids, other insects, rodents and birds at almost all stages of their development. For example, Lysiloma divaricata Hook. \& Jackson, 1895 seeds are fed upon by a species of bruchid just prior to or as they mature. When the fruits open slightly and the seeds are exposed, another species of bruchid preys upon some of the remaining seeds. The unharmed seeds that fall to the ground are then preyed upon by yet a third species of bruchid and there is evidence that rodents also take large numbers of seeds. Thus, much of the seed crop of this plant is subject to pre- and post-dispersal predation. Other species of Fabaceae from Arizona, Mexico, Guatemala, Honduras and Panama were studied to determine their bruchid predators and to some extent their means of seed dispersal. After analyzing the data Johnson (1981a) hypothesized that there are three guilds of bruchid beetles that eat seeds of the Fabaceae at different times and in different ways. These oviposition guilds evolved as a result of coevolution, sequential evolution or both. This research revealed that in the three guilds of bruchids, some species only oviposit on fruits while on the plant, other species only oviposit on seeds exposed inside fruits while still on the plant and that some only oviposit on seeds once they are exposed on the substrate. Depending on the structure of the fruits, one plant species may be oviposited upon by all three guilds, some only by two guilds and some by only one guild. The genera in the guild that oviposits on legume fruits usually are different from the genera that oviposit on seeds.

Since 1981, many papers have been published that utilize 
the concept of guilds. In addition, papers published before 1981 were examined and found to have data on oviposition in them. All of these data are incorporated into this review of bruchid oviposition guilds and evolution of the Bruchidae.

Most published papers on beetles in the family Bruchidae are economic, physiological or behavioral on economic species such as Caryedon serratus (Olivier, 1790), Acanthoscelides obtectus (Say, 1831), Zabrotes subfasciatus (Boheman, 1833), Callosobruchus maculatus (Fabricius, 1775), etc. Bruchidae, however, consists of about 1700 described species and about 66 genera grouped in the subfamilies Amblycerinae, Bruchinae, Eubaptinae, Kytorhininae, Pachymerinae, and Rhaebinae (SOUTHGATE 1979; Johnson et al. 2003). About $80 \%$ of bruchid species are in the Bruchinae, $10 \%$ in the Amblycerinae, $9 \%$ in the Pachymerinae, with the other $1 \%$ assigned to the other three subfamilies.

The larvae of all bruchids whose hosts are known feed and live in seeds of about 35 families of plants but most feed in the Fabaceae (Johnson 1981a, b, 1989; Johnson et al. 2003). According to JoHnson (1985) about $85 \%$ of the host records for bruchids are in the Fabaceae, $4 \%$ in the Arecaceae, $4 \%$ in the Convolvulaceae, and $2 \%$ in the Malvaceae. The remaining $5 \%$ are in other host plant families.

Data that are available for evolutionary relationships in the Bruchidae actually are the taxonomic schemes that have existed almost since the time of Linnaeus. That is to say, the family Bruchidae is known to be closely related to the Chrysomelidae and certainly the family is a member of the Chrysomeloidea. Therefore, we can assume that, lacking further research, this classification scheme represents the evolution of the Bruchidae. The Chrysomeloidea are made up of the Chrysomelidae, Cerambycidae and the Bruchidae. ManN \& Crowson (1981) and ReID (1995) consider the Bruchidae to be a subfamily of the Chrysomelidae. Whether the taxon is named Bruchidae or Bruchinae, the seed beetles in the taxon are still of economic importance and a very interesting group to study. Borowiec (1987) hypothesized a phylogenetic arrangement of the subfamilies and tribes of the Bruchidae. Borowiec's work is laudable because he compared many characters then hypothesized that the Bruchidae evolved from the chrysomelid subfamily Sagrinae. In his discussion he suggested that the Rhaebinae is the most primitive (plesiomorphic) subfamily of the Bruchidae. This is not in agreement with the opinion of BRIDWELL (1932) who excluded Rhaebus Fischer and Rhaebinae from the Bruchidae because "the weight of authority seems to be against considering it a bruchid". Kingsolver \& Pfaffenberger (1980), however, after an extensive and intensive study of adults and larvae of Rhaebus, concluded that Rhaebus and Rhaebinae should be assigned to the family Bruchidae. BorowIEC (1987) considered the Pachymerinae to be slightly more derived (apomorphic) than the Rhaebinae. Borowiec considered the Eubaptinae, Bruchinae and Kytorhininae to be the most specialized. He suggested that the Amblycerinae are more closely related to the Bruchinae and Kytorhininae than to other subfamilies. In general, we agree with most of Borowiec's conclusions but we disagree with his placement of the Amblycerinae. The Amblycerinae are more different morphologically and behaviorally from the other subfamilies and they are not closely related to the Bruchinae but rather the subfamily is a branch separated from the other subfamilies by a distinct gap. They are probably more closely related to the Pachymerinae than any other subfamily. Our conclusions at this time are that the Rhaebinae and Pachymerinae are the most plesiomorphic because of the ancient fossil record of the Pachymerinae and characters of both subfamilies. The Bruchinae is the most derived because it contains by far the most species and its characters are apomorphic.

A general evolutionary scheme for the Chrysomeloidea is that the Cerambycidae found a niche of feeding in wood and evolved into it, the Chrysomelidae evolved into feeding in many plant parts: leaves, twigs, roots, flowers, while the taxon now known as Bruchidae evolved in seeds of flowering plants. Therefore, each of the above taxa was formed when speciation occurred in ancestral chrysomelids by developing more specialized feeding habits. Speciation in bruchids occurred primarily by developing more and more specialized feeding habits. The approximately 11 genera in one of the most primitive subfamilies, the Pachymerinae, feed in six plant families but most species feed in either the Fabaceae or the Arecaceae. The latter subfamily is especially interesting because New World pachymerines feed only in the monocotyledonous palms and all members of the Pachymerinae feed in dicotyledonous plants except for the monocot family Pandanaceae that has been reported to be a host of an Old World bruchid. Another subfamily that is one of the more primitive, the Amblycerinae, has three genera. About 54 species of Amblycerus Thunberg, 1815 feed in seeds of about 75 different species of plants in approximately 14 families. Amblycerus has the most diverse feeding habits of any genus of bruchids. Species of Amblycerus, however, feed primarily in seeds of Fabaceae and to a lesser extent in Boraginaceae. Species of the New World Zabrotes Horn, 1885 feed in two plant families but mostly Fabaceae, while species of the Old World Spermophagus Schoenherr, 1833 feed mostly in the Malvaceae and Convolvulaceae but a few species feed in the Fabaceae. One of the more evolved subfamilies, Eubaptinae, has four species in the genus Eubaptus Lacordaire, 1845 that only feed in the plant family Acanthaceae, not in the most fedupon family, the Fabaceae. The approximately 20 species of Kytorhinus Fischer, 1809 the only genus in the more evolved subfamily Kytorhininae, feed only in papilionoid Fabaceae. Four of the approximately eight species in the genus Rhaebus, the only genus in the primitive Rhaebinae, feed only in the family Zygophyllaceae. The approximately 49 genera of the most highly evolved and largest subfamily, the Bruchinae, feed in approximately 17 families of plants. Most feed in the Fabaceae but many feed in species of Malvaceae. Acanthoscelides Schilsky, 1905, the genus with the most species in the New World, feeds in 11 families. Megacerus Fåhraeus, 1839 is a widespread genus in the New World that feeds only in the Convolvulaceae. 
Research by JoHNSON (1981a) revealed that there are three bruchid oviposition guilds that evolved as a result of coevolution, sequential evolution or both. This research revealed that in the three guilds of bruchids some species only oviposit on fruits while on the plant, other species only oviposit on seeds exposed while still on the plant and that some only oviposit on seeds once they are exposed on the substrate. One plant species may be oviposited upon by all three guilds, some only by two guilds and some by only one guild.

\section{METHODS}

Research on bruchid oviposition guilds requires that extensive work be done in the natural habitat of plants and bruchids so that seeds and fruits with bruchids in them can be observed there. Studies in natural habitats are necessary because once the seeds are taken to the laboratory, the oviposition behavior is significantly different when confined in containers. In containers in the laboratory, females oviposit on almost anything when a surface is encountered that releases oviposition.

Fruits were gathered from plants or exposed seeds were gathered from the ground beneath plants. Fruits were placed in brown paper bags and individual seeds were placed in gelatin capsules and/or cardboard pill boxes. The seeds and fruits were examined in the laboratory for adult bruchids that had emerged, and the fruits were then placed in fruit jars with ring tops and paper towels for lids. The seeds were then examined every 7-10 days and the adult bruchids removed as long as adults continued to emerge from the seeds. The adult bruchids were mounted, identified and then counted. We therefore believe this system to be accurate although some may have failed to emerge from seeds. Most seeds for this study were collected in Latin America. Because of agricultural expansion, overgrazing of natural areas, and ease of access, most collections were in roadside areas where plants and seeds were most abundant. The results, then, probably do not represent a totally natural situation but rather one that has been modified considerably by man.

The data presented in this paper are based on the collection of thousands of seeds and the rearing of thousands of bruchid beetles from them. Most of the seeds were gathered for qualitative assessment of host preferences of bruchids and their parasites, not for a quantitative study of seed damage or destruction by the various bruchid guilds.

\section{RESULTS}

\section{THE PLANTS}

We classify the plants according to whether they have (A) dehiscent fruits, (B) partially dehiscent fruits, or (C) indehiscent fruits. All species are known hosts for at least one species of Bruchidae but some are known to have their seeds fed upon by several species (JoHnson 1981a).
A. Dehiscent fruits. Fruits of these species when mature dehisce almost explosively and seeds are scattered in the immediate vicinity of the plant, with perhaps $10 \%$ of the seeds adhering to the open fruits. The fruit valves eventually fall to the ground and may be blown away by the wind. Seeds of plants in this group are probably first dispersed by the initial elastic dehiscence of the fruits and then subsequently by gravity, possibly water, and/or scatter hoarding by small rodents. Seeds of Calliandra humilis and C. eriophylla Bentham, 1844 are very often found in natural crevices, depressions, and under rocks, where they presumably have been carried by the above forces. Seeds adhering to the fruit valves may be dispersed when the wind blows the valves after they have fallen to the ground.

B. Indehiscent fruits. Species in this group are all trees or shrubs (e.g., Acacia cochliacantha Humb. \& Bonpl. ex Willd., 1806 (=A. cymbispina), A. farnesiana (L.) Willd., 1806, Enterolobium cyclocarpum (Jacq.) Griseb., 1860. Fruits of these species are sometimes considered to be tardily dehiscent but it may be several months before they open enough to expose the seeds. Often they fall to the substrate where the mostly woody fruits deteriorate to expose the seeds. Seeds in this group are probably dispersed when birds or large, native or introduced mammals eat the woody fruits, digest the pulp, and pass the seeds through the digestive tract intact. Some palm seeds are carried by rodents from under the parent plant where they are either eaten or scatter hoarded. Examination of partially decomposed cow dung in several areas of Latin America revealed many intact seeds of various species with bruchid eggs on them. These seeds were collected and subsequently adult bruchids emerged from them. In San Carlos, Panama, the first author observed that poisonous seeds of Enterolobium cyclocarpum are dispersed by cattle that eat the thick, sweet fruit valves that contain viable seeds that pass intact through the guts of these vertebrates. Stator generalis Johnson \& Kingsolver, 1976 eggs were glued to these seeds and adult bruchids emerged from them.

Palm fruits (Arecaceae) fall to the ground usually intact. The first author has observed that the smooth seeds (endocarp) of Sabal Adanson, 1763 species are only oviposited upon by Caryobruchus gleditsiae Linnaeus, 1763 after the exocarp and mesocarp are removed, probably by rodents. This behavior has also been observed in other bruchids and palms by several authors, e. g., WILSON \& JANZEN (1972) in Scheelea rostrata (Oerst.) Burret, 1929 and SiLvius (2002) in Attalea maripa (Aubl.) Mart., 1844 (Table 3).

C. Partially dehiscent fruits. Species in this group are all woody trees or shrubs. Fruits of these species mature slowly, the valves open slightly on the plant, the seeds fall from the slightly opened fruits over a period of days or weeks, and eventually the fruit valves fall to the substrate. Some species (e.g., Pithecellobium sonorae S. Watson, 1889, Albizia Durazz., 1772 spp., Acacia coulteri Bentham ex A. Gray, 1852) do not drop many seeds from the fruits while they are on the tree but 
Table I. Mature Fruit Guild A: bruchids that oviposit only on fruit walls. Hosts for bruchids in this guild are from the following publications: Bagdasaryan (1941); BASKin \& BASkin (1977); CEnTER \& JohnSon (1973, 1974); Forister \& Johnson (1970, 1971); JANZEN (1982); Johnson (1974, 1977a, b; 1978, 1981a, 1998); Johnson \& Kingsolver (1975); Johnson \& Siemens (1991, 1995, 1997a, b); Johnson et al. (2001); Muruaga de L'argentier (1991); Muruaga de L'argentier \& Terán (1980); Ribeiro-costa (1998); Ribeiro-costa \& Costa (2002); Southgate (1979); Terán (1962, 1967, 1984); Terán \& Muruaga de de L'argentier $(1979,1981)$.

Acanthoscelides alboscutellatus (Horn, 1873)

A.baboquivari Johnson, 1974

A. chiricahuae (Fall, 1910)

A. compressicornis (Schaeffer, 1907)

A. fraterculus (Horn, 1873)

A. kingsolveri Johnson, 1974

A. lobatus (Fall, 1910)

A. longescutus (Pic, 1938)

A. mundulus (Sharp, 1885)

A. oblongoguttatus (Fåhraeus, 1839)

A. pallidipennis (Motschulsky, 1874)

A. prosopoides (Schaeffer, 1907)

A. siemensi Johnson, 1991

A. submuticus (Sharp, 1885)

Algarobius johnsoni Kingsolver, 1986)

A. prosopis (Leconte, 1858)

A. riochama Kingsolver, 1986

Amblycerus dispar (Sharp, 1885)

A. cistelinus (Gyllenhal, 1833)

A. crassipunctatus Ribeiro-Costa, 1999

A. hoffmanseggi (Gyllenhal, 1833)

A. nigromarginatus (Motschulsky, 1874)

A. piurae (Pierce, 1915)

A. submaculatus (Pic, 1927)

A. testaceus (Pic, 1917)

A. vitis (Schaeffer, 1907)

Bruchidius strangulatus (Fåhraeus, 1839)

Bruchus brachialis Fåhraeus, 1839

B. pisorum (Linnaeus, 1758)

Caryedes brasiliensis (Thunberg, 1816)

C. grammicus (Gyllenhal, 1833)

Caryedon fasciatus Prevett, 1965

C. germari (Küster, 1845)

Ctenocolum janzeni Kingsolver \& Whitehead, 1974)

Eubaptus rufithorax (Pic, 1928)

Megacerus baeri (Pic, 1934)

M. discoidus (Say, 1824)

M. schaefferianus Bridwell, 1929

Merobruchus bicoloripes (Pic, 1929)

M. boucheri Kingsolver, 1980

M. chetumalae Kingsolver, 1988

M. columbinus (Sharp, 1885)

M. insolitus (Sharp, 1885)
M. julianus (Horn, 1894)
M. knulli (White, 1941)
M. major (Fall, 1912)
M. paquetae Kingsolver, 1980
M. placidus (Horn, 1873)
M. porphyreus Kingsolver, 1988
M. santarosae Kingsolver, 1980
M. solitarius (Sharp, 1885)
M. sonorensis Kingsolver, 1980
M. terani Kingsolver, 1980
M. triacanthus Kingsolver, 1988
M. vacillator (Sharp, 1885)
M. xanthopygus Kingsolver, 1988

Mimosestes acaciestes Kingsolver \& Johnson, 1978

M. amicus (Horn, 1873)

M. janzeni Kingsolver \& Johnson, 1978

M. mimosae (Fabricius, 1781)

M. nubigens (Motschulsky, 1874)

Neltumius arizonensis (Schaeffer, 1904)

N. gibbithorax (Schaeffer, 1904)

N. texanus (Schaeffer, 1904)

Penthobruchus germaini (Pic, 1894)

Pseudopachymerina spinipes (Erichson, 1834)

Pygiopachymerus lineola (Chevrolat, 1871)

Rhipibruchus atratus Kingsolver, 1982

R. jujuyensis Muruaga de L'Argentier \& Kingsolver, 1884

R. oedipygus Kingsolver, 1982

R. picturatus (Fåhraeus, 1839)

R. prosopis Kingsolver, 1967

R. psephenopygus Muruaga de L'Argentier \& Kingsolver, 1884

R. rugicollis Kingsolver, 1982

Scutobruchus ceratioborus (Philippi, 1859)

Sennius abbreviatus (Say, 1824)

S. laminifer (Sharp, 1885)

S. leptophyllicola Ribeiro-Costa \& Costa, 2002

S. medialis (Sharp, 1885)

S. morosus (Sharp, 1885)

S. simulans (Schaeffer, 1907)

Stator bisbimaculatus (Pic, 1930)

S. monachus (Sharp, 1885)

S. trisignatus (Sharp, 1885)

S. vittatithorax (Pic, 1930). 
rather the dehisced fruit valves fall from the plants with many of the seeds still attached to the valves. Seeds in this group are probably dispersed as described above.

\section{THE BRUCHIDS}

We have classified 115 species of bruchids (Tables I, II, III) according to the evolution of their oviposition behavior patterns. Three guilds are recognized: (A) the Mature Fruit Guild oviposits only on the surfaces of fruits (Table I); (B) the Mature Seed Guild oviposits only on mature seeds still in fruits on the plant (Table II); and (C) the Scattered Seed Guild oviposits only on mature seeds after they have fallen to the ground (Table III). Many species of bruchids are listed in the tables and with more information more species of bruchids could be listed in all guilds.

A. Mature Fruit Guild (A). The 88 members of this group, together with their hosts, are listed in Table I. They feed mostly in the plant family Fabaceae, to a lesser extent in the Convolvulaceae, and also in the Verbenaceae, Rhamnaceae, Vitaceae, Acanthaceae, Zygophyllaceae, Onagraceae, and Humiriaceae. These species either glue their eggs to the outside of the fruit, oviposit in crevices in the fruit wall or between the calyx and fruit and their larvae burrow through the fruit wall into seeds. Most Merobruchus Bridwell, 1946 have but one generation per year in the seeds of their hosts but some species of Acanthoscelides and Mimosestes Bridwell, 1946 may continue to breed in seeds of their hosts as long as seeds are available. Mimosestes spp. usually feed upon only indehiscent fruits but Acanthoscelides spp. and Merobruchus spp. usually feed only in fruits that are partially dehiscent. Apparently to prevent themselves and pupae from falling from the fruit when inside the seeds, many Merobruchus spp. larvae glue seed or seeds to the fruit valve where they complete their development while the fruit remains attached to the plant.

B. Mature Seed Guild (B). As with other species of bruchids, the 11 species in this guild may breed in seeds until the food source has been completely utilized (Table II). Their hosts are mostly in the family Fabaceae and one species in the Sterculiaceae. Because they breed very prolifically in the laboratory, it is highly probable that they breed in concentrated resources such as seed caches under natural conditions. Stator limbatus and S. pruininus (Horn, 1873) have been reported to feed in up to 74 and 55 host species respectively (JOHNSON \& SIEMENS 1995).

C. Scattered Seed Guild (C). Some species in the genus Stator Bridwell, 1946 were once rare in collections because usual collecting methods do not yield large numbers of insects. Collecting seeds from the ground, however, is a most efficient method of obtaining specimens but also new host records as well. This group contains 15 species (Table III). Species in this guild show some unique host preferences. Stator sordidus (Horn, 1873), S. chihuahua Johnson \& Kingsolver, 1976 and
Table II. Mature seed guild B: Bruchids that oviposit only on mature seeds while in the fruit on the plant. Hosts for bruchids in this guild are from the following publications: CENTER \& JOHNSON (1974); Johnson (1981a); Johnson \& Siemens (1995); Nilsson \& Johnson (1993b).

Acanthoscelides guazumae Johnson \& Kingsolver, 1971

Bruchidius natalensis (Pic, 1913)

B. schoutedeni (Pic, 1924)

Sennius fallax (Boheman, 1839)

S. bondari (Pic, 1929)

Specularius impressithorax (Pic, 1932)

Stator beali Johnson, 1963

S. championi (Sharp, 1885)

S. limbatus (Horn, 1873)

S. pruininus (Horn, 1873)

Zabrotes interstitialis (Chevrolat, 1871)

Z. subfasciatus (Boheman, 1833).

S. pygidialis feed in seeds from dehiscent or partially dehiscent fruits and are not known to feed in seeds from indehiscent fruits. S. vachelliae feeds in ten species of hosts but mostly in seeds from fruits of indehiscent acacias after the fruit valves rot or cattle eat them. S. generalis exhibits the same behavior but only in the seeds of Enterolobium cyclocarpum. All 15 species have hosts that are unique to them. Stator generalis has only one host. S. chihuahua has five, S. sordidus has 16 and $S$. pygidialis has two. Thus, the species of the scattered seed guild of Stator show more specificity when compared to their Stator relatives in guild B. All species in this guild are continuous breeders. In an effort to determine whether chemical or behavioral factors were responsible for this specificity, several species of bruchids were exposed to several non-host species of plant seeds in the laboratory. Under experimental conditions, $S$. sordidus was able to feed and mature in 16 species of plants not known to be its hosts. The 16 included seeds from indehiscent fruits. JOHNSON (1981a) reported this behavior of $S$. sordidus and stated that it fed in only two species naturally. He also stated that two other species do not breed freely in the laboratory. When more research is done on this guild, it may be found that these bruchids are not as specific as JOHNSON (1981a) thought when he reported the two hosts for $S$. sordidus as opposed to the 16 hosts that we now know that it feeds upon in nature. $S$. vachelliae could only mature in seeds of Acacia hindsii Bentham, 1842 and Prosopis juliflora (Sw.) DC., 1825 of the 16 species it was tried against in the laboratory. We now know that it feeds in 10 species in nature. Acacia hindsii is tardily dehiscent and its seeds are surrounded by pulp. Prosopis juliflora seeds are surrounded by a thick pulp. Under laboratory conditions S. chihuahua bred freely only in seeds from fruits 
of four species of partially dehiscent legumes (JoHnson \& KingSOLVER 1976; JoHNSON 1979).

\section{DISCUSSION}

Based on the evolutionary pattern described above for Bruchidae from the other Chrysomeloidea, it seems logical that bruchids initially oviposited on the surface of fruits in evolutionary time. The larvae then fed upon the nutrient-rich seeds by burrowing through the walls of the fruits. In time it appears that most bruchid larvae would have had to be able to utilize the nutrients in the seeds and the genetic feedback to the adult females to oviposit on the fruits would have had to be evolved. Then more specificity occurred as plants developed better ways to distribute their seeds. Bruchids in turn evolved mechanisms for ovipositing on fruits in seeds in which they prospered, so that through time most bruchids first oviposited on fruit walls then had to evolve mechanisms to find and oviposit on seeds that were dispersed in different ways by plants. Then the various oviposition behaviors developed as described here. If this hypothesis is valid then there should be more oviposition by bruchids on walls of fruits. In the data here, 88 species of bruchids oviposit on fruit walls, 11 oviposit on seeds inside fruits, and 15 oviposit on seeds that are on the substrate.

For reasons that are explained below, we believe that the structure and behavior of seeds and fruits of most plants in this study are a result of combined selective pressure for seed dispersal and for protection from seed predators. For example, small seeds probably pass through an animal's gut more easily than large seeds and also may escape mastication when mammals chew the fruits. One probable reason that many indehiscent leguminous fruits have thick, nutritious valves is to attract birds and large mammals that disperse seeds they feed upon. The large vertebrates digest the fruit valves, and pass intact seeds through the digestive tract unharmed. Seeds with bruchids inside them are often digested along with the bruchids in them because of the entry hole of bruchid larvae (LAMPREY et al. 1974).

According to JoHNSON (1981a) dehiscent and partially dehiscent fruits probably disperse their seeds by gravity and scatter hoarding by small rodents. Those plants with partially dehiscent fruits that release only part of their seeds while on the plant while some seeds adhere to a fruit valve even after it falls to the substrate are probably dispersed by the wind blowing the very light fruit valves. It is doubtful that birds disperse seeds from dehiscent or partially dehiscent fruits because these seeds do not usually have a coating of any kind that has much food value; most of the food value is the seed embryo. Therefore, if the seeds were to be ingested the entire embryo would most likely be digested. In terms of escape from bruchid seed predators, it would appear that dehiscent fruits have the most effective mode of escape. Both bruchid guilds A and B (Tables I, II) are almost completely eliminated from feeding in these seeds and if the seeds are effectively scattered then they are not preyed upon by bruchid guild C,
Table III. Scattered Seed Guild C: Bruchids that oviposit only on mature seeds or fruits on the substrate. Hosts for bruchids in this guild are from the following publications: BOtTIMER (1973); BRADFORD \& Smith (1977); Delobel et al. (1995); Johnson (1981a); Johnson \& Siemens (1992); Nilsson \& Johnson (1993a); Silvius (2002); Wilson \& JANZEN (1972).

Caryoborus gracilis (Nilsson, 1993)
C. serripes (Sturm, 1826)

Caryobruchus gleditsiae (Johansson \& Linnaeus, 1789)

Pachymerus cardo (Fåhraeus, 1839)

Speciomerus giganteus (Chevrolat, 1877)

Stator chihuahua Johnson \& Kingsolver, 1976

S. generalis Johnson \& Kingsolver, 1976

S. mexicanus Bottimer, 1973

S. pygidialis (Schaeffer, 1907)

S. sordidus (Horn, 1873)

S. subaeneus (Schaeffer, 1907)

S. testudinarius (Erichson, 1847)

S. vachelliae Bottimer, 1973

although the percentage fed upon by rodents is not known. The disadvantages to the plant species are that the seeds are probably not dispersed very far from the parent plant.

The plants with indehiscent, usually somewhat woody fruits have effectively eliminated bruchid guild $\mathrm{B}$. The available evidence indicates that seeds in these fruits are dispersed when mammals feed on the fruits and the seeds pass through the digestive tract in a viable condition. Thus the energy expenditure in producing fruit valves is probably to attract a large animal to eat the valves and thus disperse the seeds and also to protect the seeds from bruchid guild B. CEnTER \& JoHNSON (1974) pointed out that of 31 protective traits for seeds (JANZEN 1969), only seven are concerned with protective devices in the fruits and that over $62 \%$ of the bruchid species they studied oviposited on the fruit wall, not directly on the seed. In this study we found that about $78 \%$ oviposit on fruit walls. Because fruit walls have few protective devices and presumably few toxins in them, an obvious hypothesis to explain this phenomenon is that non-toxic indehiscent fruit valves are modified to attract dispersal agents.

Seeds that are not dispersed by vertebrate dispersal agents are released when the fruits deteriorate on the ground but may be dispersed later by scatter hoarding by small rodents. Guild $\mathrm{A}$ is sometimes known to continue to breed in these plants and, of course, guild $\mathrm{C}$ feeds in seeds exposed when the fruit valves deteriorate.

The advantages of those plants with partially dehiscent fruits are difficult to determine. The seeds are fed upon by all three guilds of bruchids and most likely small mammals and perhaps birds. The seed-dispersing period may take place over 
an extended period of time ( 3 to 4 months in Lysiloma divaricata) thus the seeds are preyed upon by a variety of organisms. Perhaps scatter hoarding by rodents plays a major role in dispersing them. An explanation for this is that bruchid predation pressure has driven these plants to evolve fruit and seed mechanisms for dispersal and perhaps to satiate predators. MCKEY (1975) states that in those plants with a relatively small crop of large high-quality seeds there is more selection for seed dispersal by specialized animals. He also states that in plants that produce a great number of small seeds there is selection for a fruit that is exploitable by a wide variety of animals. The latter seems to be what we have observed here. Because so many different species of bruchids with different methods of preying on seeds ovipositing upon plants with partially dehiscent fruits at all stages of seed dispersal, these pressures should result in easily identifiable defensive traits or necessitate identifying a multitude of traits. Perhaps partially dehiscent fruit species, which may have higher visibility to dispersal agents, are highly dependent on rapid dispersal by birds. Habitats modified by man may contain fewer seed-dispersing birds; hence the longer residence time of seeds may mean higher predation by bruchids.

Each of the 3 guilds of bruchids is not unique to a specific pattern of seed dispersal. Each guild preys upon seeds when they are vulnerable and all 3 guilds may feed in plants with partially dehiscent fruits. JoHNSON (1981a) thought bruchids in Guild C (Table III) were specific to their host seeds and that it would be expected that they would have many hosts because they feed in a very scarce, diffuse resource (dispersed seeds). Thus, any of several hosts would suffice for reproduction. We have shown here that with further research that the hypotheses of JoHnson (1981a) were indeed true.

Stator limbatus and S. pruininus are the two members of Guild B that we have accurate host data for feed in seeds of up 74 and 55 species of plants respectively. This is also unusual because the seeds that they feed in have yet to be dispersed and are therefore more numerous and more easily found by bruchids. Perhaps plants with seed protective devices such as fruits that partially dehisce but produce many seeds, protect their seeds in fruits by allowing many of their seeds to fall to the substrate before they can be oviposited upon by Guild B bruchids. Then they are exposed to oviposition by Guild C.

No matter what the explanation is for the structure and behavior of the various kinds of fruits, it is very obvious that the phenomena of seed dispersal and seed predation in plants, when studied much more intensively, will provide answers to many ecological and evolutionary questions.

Acknowledgment. We gratefully acknowledge the support of the Department of Biological Sciences, Northern Arizona University and the Programa de Entomología y Acarología, CEIFIT, Colegio de Postgraduados for support for this research. Funds for gathering and processing seeds and bruchids were provided by grants 12-14-1009187(33) and 12-14-100-9970(33) from the IIBIII, U.S. Department of Agriculture, while funds for collecting and analysis of data were provided by NSF Grant DEB78-05962. We also thank two anonymous reviewers and Dra. C. S. Ribeiro-Costa for general help with the manuscript and for translating English into Portuguese.

\section{REFERENCES}

Bagdasaryan, B. A. 1941. The seed beetles of the Armenian SSR and their relationships with plants, particularly Leguminosae. Scientific Publication of the Erevan State University (Nauchnii Trud Erevansii Gosudarskii Universitet) 16: 309374. (In Russian).

Baskin, J. M. \& C. C. BAskin. 1977. Predation of Cassia marilandica seeds by Sennius abbreviatus (Coleoptera: Bruchidae). Bulletin of the Torrey Botanical Club 104(1): 61-64.

Borowiec, L. 1987. The genera of seed-beetles. Polskie Pismo Entomologiczne 57: 3-207.

Bottimer, L. J. 1973. Two new American bruchids in the sordidus group of Stator (Coleoptera: Bruchidae) with notes on other species. Canadian Entomologist 105: 545-51.

BradFord, D. F. \& C. C. Sмith. 1977. Seed predation and seed number in Scheelea palm fruits. Ecology 58: 667-673.

Bridwell, J. C. 1932. The subfamilies of the Bruchidae (Coleoptera). Proceedings of the Entomological Society of Washington 34(6): 100-106.

Center, T. D. \& C. D. Johnson. 1973. Comparative life histories of Sennius (Coleoptera: Bruchidae). Environmental Entomology 2(4): 669-672.

Center, T. D. \& C. D. Johnson. 1974. Coevolution of some seed beetles (Coleoptera: Bruchidae) and their hosts. Ecology 55: 1096-1103.

Delobel, A.; G. Couturier; F. Kahn \& J. A. Nilsson. 1995. Trophic relationships between palms and bruchids (Coleoptera: Bruchidae: Pachymerini) in Peruvian Amazonia. Amazoniana 13(3-4): 209219.

Forister, G. W. \& C. D. Johnson. 1970. Bionomics of Merobruchus julianus (Coleoptera: Bruchidae). Coleopterists' Bulletin 24(3): 84-87.

Forister, G. W. \& C. D. Johnson. 1971. Behavior and ecology of Acanthoscelides prosopoides (Coleoptera: Bruchidae). Pan Pacific Entomologist 47(3): 224-234.

JANZEN, D. H. 1969. Seed-eaters versus seed size, number, toxicity and dispersal. Evolution 23: 1-27.

JANZeN, D. H. 1982. Natural history of guacimo fruits (Sterculiaceae: Guazuma ulmifolia) with respect to consumption by large mammals. American Journal of Botany 69(8): 1240-1250.

Johnson, C. D. 1974. Ecology of two Acanthoscelides from Indigofera, with a description of a new species (Coleoptera: Bruchidae). Journal of the Kansas Entomological Society 47(2): 268278.

Johnson, C. D. 1977a. Two new species of Acanthoscelides (Coleoptera: Bruchidae) from North America and new bruchid host records from Desmanthus and Hoffmanseggia (Leguminosae). Pan Pacific Entomologist 53: 60-73.

Johnson, C. D. 1977b. Three new species of Sennius from Mexico and Central America, with new host records for other Sennius (Coleoptera: Bruchidae). Coleopterists Bulletin 31(2): 117131.

Johnson, C. D. 1978. Ecology of Neltumius texanus (Coleoptera: Bruchidae) in seeds of Condalia (Rhamnaceae). Journal of the Kansas Entomological Society 51(3): 432-440.

Johnson, C. D. 1979. New host records in the Bruchidae. Coleopterists Bulletin 33: 121-124.

Johnson, C. D. 1981a. Interactions between bruchid (Coleoptera) feeding guilds and behavioral patterns of fruits of the Leguminosae. Environmental Entomology 10: 249-253.

Johnson, C. D. 1981b. Seed Beetle Host Specificity and the Systematics of the Leguminosae, p. 995-1027, + 61 pp. microfiche. In: R. M. Polhill \& P. H. Raven (eds.). Advances in Legume Systematics. Kew, Royal Botanic Gardens, xvi+1050 p. in two parts.

Johnson, C. D. 1985. Potential Useful Tropical Legumes and Their Relationships with Bruchid Beetles, p. 206-210. In: K. C. MisrA (ed.). Ecology and Resource Management in Tropics. Vol. 1. Presented Papers, Silver Jubilee Symposium of International Society for Tropical Ecology. Varanasi, Bhargava Book Depot, $x i+324$ p. 
Johnson, C. D. 1989. Adaptive Radiation of Acanthoscelides in Seeds: Examples of Legume Bruchid Interactions, p. 747-779. In: C. H. Stirton \& J. L. Zarucchi (eds.). Advances in Legume Biology, Monographs in Systematic Botany Missouri Botanical Garden. 842 p.

Johnson, C. D. 1998. New host records, distribution and notes on the behavior of some seed beetles (Coleoptera: Bruchidae). Coleopterists Bulletin 52(2): 147-149.

Johnson, C. D. \& J. M. KingSOLver. 1975. Ecology and redescription of the Arizona grape bruchid Amblycerus vitis (Coleoptera). Coleopterists Bulletin 29(4): 321-331.

Johnson, C. D. \& J. M. Kingsolver. 1976. Systematics of Stator of North and Central America (Coleoptera: Bruchidae). United States Department of Agriculture Technical Bulletin 1537: 1-101.

Johnson, C. D. \& D. H. Siemens. 1991. Interactions between a new species of Acanthoscelides and a species of Verbenaceae, a new host family for Bruchidae (Coleoptera). Annals of the Entomological Society of America 84(2): 165-169.

Johnson, C. D. \& D. H. Siemens. 1992. Observations on host plant and biogeographical differences in bruchid beetles in southern Ecuador. Biotropica 24(2a): 195-199.

Johnson, C. D. \& D. H. Siemens. 1995. Bruchid guilds, host preferences, and new host records from Latin America and Texas for the genus Stator (Coleoptera: Bruchidae). Coleopterists Bulletin 49(2): 133-142.

Johnson, C. D. \& D. H. Siemens. 1997a. Oviposition behavior, guilds, host relationships and new host and distribution records for the genus Merobruchus Bridwell (Coleoptera: Bruchidae). Coleopterists Bulletin 51(1): 13-21.

Johnson, C. D. \& D. H. Siemens. 1997b. Distribution, oviposition guilds, behavior and new host records from Latin America for Algarobius Bridwell, Scutobruchus Kingsolver and Pseudopachymerina spinipes (Erichson) (Coleoptera: Bruchidae). Coleopterists Bulletin 51(1): 37-42.

Johnson, C. D.; J. Romero \& E. Raimúndez-urrutia. 2001. Ecology of Amblycerus crassipunctatus Ribeiro-Costa (Coleoptera: Bruchidae) in seeds of Humiriaceae, a new host family for bruchids, with an ecological comparison to other species of Amblycerus. Coleopterists Bulletin 55(1): 37-48.

Johnson, C. D.; B. J. Southgate \& A. Delobel. 2003. A Revision of the Caryedontini (Coleoptera: Bruchidae: Pachymerinae) of Africa and the Middle East. Memoirs of the American Entomological Society 44: 1-120.

Kingsolver, J. M. \& C. D. Johnson. 1978. Systematics of the genus Mimosestes (Coleoptera: Bruchidae). U.S. Department Agriculture Technical Bulletin 1590. 106 p.

Kingsolver, J. M. \& G. S. Pfaffenberger. 1980. Systematic relationship of the Genus Rhaebus (Coleoptera: Bruchidae). Proceedings of the Entomological Society of Washington 82(2): 293-311.

Lamprey, H. F., Halevy, G. \& MaKacha, S. 1974. Interactions between Acacia, bruchid seed beetles, and large herbivores. East African Wildlife Journal 12: 81-85.

Mann, J. S. \& R. A. Crowson. 1981. The systematic position of Orsodacne Latr. and Syneta Latr. (Coleoptera Chrysomelidae), in relation to characters of larvae, internal anatomy and tarsal vestiture. Journal of Natural History 15(5): 727-749.

McKey, D. 1975. The Ecology of Coevolved Seed Dispersal Systems, p. 159-191. In: L. E. Gilbert \& P. H. Raven (eds.). Coevolution of
Animals and Plants.Austin, University of Texas Press, 246 p.

Muruaga de L'argentier, S. 1991. Bruchidae del noroeste argentino: estudios morfológicos y biológicos de las especies de Rhipibruchus Bridwell. Acta Zoologica Lilloana 40(2): 39-77.

Muruaga de L'Argentier, S. M. \& A. L. Terán. 1980. Observaciones sobre Bruchidae (Coleoptera) del noroeste Argentino III. Estudios morfológicos y biológicos de Megacerus (M.) baeri Pic y Acanthoscelides nigronotaticeps (Pic), Bruchinae. Acta Zoologica Lilloana 36(1): 57-75.

Nilsson, J. A. \& C. D. Johnson. 1993a. A Taxonomic Revision of the Palm Bruchids (Pachymerini) and a Description of the World Genera of Pachymerinae (Coleoptera: Bruchidae: Pachymerinae). Memoirs of the American Entomological Society 41: 1-104.

Nilsson, J. A. \& C. D. Johnson. 1993b. Laboratory hybridization of Stator beali and $S$. limbatus, with new host records for S. limbatus and Mimosestes amicus (Coleoptera: Bruchidae). Southwestern Naturalist 38(4): 385-387.

ReID, C. 1995. A cladistic analysis of subfamilial relationships in the Chrysomelidae sensu lato (Chrysomeloidea), p. 559-631. In: J. Pakaluk \& S. A. Slipinski (eds.). Biology, Phylogeny, and Classification of Coleoptera. Papers Celebrating the $80^{\text {th }}$ Birthday of Roy A. Crowson. Warsaw, Museum i Instytut Zoologii PAN.

Ribeiro-Costa, C. S. 1998. Observations on the biology of Amblycerus submaculatus (Pic) and Sennius bondari (Pic) (Coleoptera: Bruchidae) in Senna alata (L.) Roxburgh (Caesalpinaceae). Coleopterists Bulletin 52(1): 63-69.

Ribeiro-Costa, C. S. \& A. S. Costa. 2002. Comportamento de oviposição de Bruchidae (Coleoptera) predadores de sementes de Cassia leptophylla Vogel (Caesalpinaceae), morfologia dos ovos e descrição de uma nova espécie. Revista Brasileira de Zoologia 19 (Supl. 1): $305-316$.

SiLvius, K. M. 2002. Spatio-temporal patterns of palm endocarp use by three Amazonian forest mammals: granivory or 'grubivory'? Journal of Tropical Ecology 18: 707-723.

Southgate, B. J. 1979. Biology of the Bruchidae. Annual Review of Entomology 24: 449-473.

Terán, A. L. 1962. Observaciones sobre Bruchidae (Coleoptera) del noroeste argentino. Acta Zoologica Lilloana 18: 211-242.

TERÁn, A. L. 1967. Consideraciones sobre Eubaptus palliatus Lac., Bruchus scapularis Pic y descripción de los estados preimaginales de Eubaptus rufithorax (Pic). Acta Zoologica Lilloana 21: 7189.

TERÁn, A. L. 1984. Observaciones sobre Bruchidae (Coleoptera) del noroeste argentino. VI. Estudios morfológicos y biológicos de Amblycerus testaceus. Acta Zoologica Lilloana 35(1): 435-474.

Terán, A. L. \& S. Muruaga de L'Argentier. 1979. Observaciones sobre Bruchidae (Coleoptera) del noroeste argentino. II. Estudios morfológicos e biológicos de algunas espécies de Amblycerinae y Bruchinae. Acta Zoologica Lilloana 35(1): 435-474.

Terán, A. L. \& S. Muruaga de L'Argentier. 1981. Observaciones sobre Bruchidae (Coleoptera) del noroeste argentino. IV. Estudios morfológicos y biológicos de Amblycerus hoffmanseggi (Gyll.), Acanthoscelides comptus Kingsolver y Merobruchus bicoloripes (Pic). Acta Zoologica Lilloana 36(2): 61-84.

WiLson, D. E. \& D. H. JANZEN. 1972. P redation on Scheelea palm seeds by bruchid beetles: seed density and distance from the parent tree. Ecology 53: 954-959.

Received 27.II.2004; accepted 30.VII.2004 